UDC: $577.346+612.117+612.111 .6+616.066$

DOI: $10.15587 / 2313-8416.2015 .47546$

\title{
INFLUENCE OF CANCER DISEASE ON DIELECTRIC CHARACTERISTICS OF STRUCTURAL-FUNCTIONAL STATE OF ERYTHROCYTE MEMBRANES
}

\begin{abstract}
(C) L. Batyuk
Aim. To define the character of mutagenic influence of cancer disease on the dielectric relaxation frequency of the water molecules in suspensions and erythrocyte ghosts in diapason of ultrahigh frequencies (UHF).

Methods. The study of dielectric relaxation frequency of the water molecules in solutions of erythrocytes and erythrocyte ghosts was carried out with the method of measurements of an actual $\left(\varepsilon^{\prime}\right)$ and imaginary $\left(\varepsilon^{\prime \prime}\right)$ parts of complex dielectric permeability. The value of dielectric constant $\varepsilon^{\prime}$ was defined by the measurement of the resonance frequency ( $\Delta f)$ of resonator with pattern relative to an empty resonator and the value $\varepsilon^{\prime \prime}$ - by the value of damping of power of UHF field as a result of introduction of dielectric in resonator.

Results. There were received the temperature dependencies of dielectric permeability for suspensions and erythrocyte ghosts in donors and cancer patients. In suspension of donor erythrocytes in temperature area 6-12, 17-40 and $43-46{ }^{\circ} \mathrm{C}$ and in suspension of erythrocytes of patients at temperatures 9-18, 23-37 and 43-46 ${ }^{\circ} \mathrm{C}$, it were observed the deviation of dielectric indicators from the monotonous growth that was attended by the reliable growth of the dielectric relaxation frequency fd of the water molecules in suspension of patient erythrocytes compared with the dielectric relaxation frequency fd of the water molecules in suspension of donor erythrocytes. There were calculated the values of energy of time activation of dielectric relaxation of the water molecules in given systems. Conclusions. It was detected the growth of the dielectric relaxation frequency of the water molecules in suspension of erythrocytes of cancer patients in temperature interval $1-46^{\circ} \mathrm{C}$ compared to the dielectric relaxation frequency of the water molecules in suspension of erythrocytes of the healthy donors. It was revealed that in temperature diapason $6-12{ }^{\circ} \mathrm{C}, 43-46{ }^{\circ} \mathrm{C}$ in suspension of donor erythrocytes and in temperature diapason $9-18^{\circ} \mathrm{C}, 23-37^{\circ} \mathrm{C}$, 43-46 ${ }^{\circ} \mathrm{C}$ in suspension of erythrocytes of cancer patients take place the changes of the state of water that leads to loosening of the structure of lipid biolayer of membrane
\end{abstract}

Keywords: erythrocytes, erythrocyte ghosts, dielectric relaxation frequency, dielectric permeability, hydration, temperature

Досліджено залежність зміни частоти діелектричної релаксації молекул води в суспензіях і тінях еритроциттів в інтервалі температур 1-46 ${ }^{\circ}$ в в нормі та при онкології. Отримано, ш⿻о в клітинах спостерігається зміна співвідношення вільної та зв'язаної води. Розрахована енергія активації діелектричної релаксації молекул води в суспензіях еритроцитів донорів та онкологічних хворих

Ключові слова: еритроцити, тіні еритроцитів, частота діелектричної релаксацї, діелектрична проникність, гідратаиія, температура

\section{Introduction}

The cancer rate in the world grows slowly but steadily [1]. Pathologic changes of physical and metabolic processes in organism that have mutagenic influence on organism lead to the changes on the cellular level. Taking into account the generality of structural organization and peculiarities of functioning of erythrocytic and other cellular membranes, there was admitted an ability of erythrocyte membrane to reflect the state of cells and to be an indicator of the measure of its involvement in pathologic process [2]. It is clearly presented at inflammatory processes of the different localization, influence of the toxic chemical substances, malignant tumor growth [3]. In spite of the great number of publications devoted to the study of properties of the red blood cells with the water as a solvent it stay the one of the most complicated and little-studied systems [4-7]. According to many authors [8-10], the changes observing in functional state of erythrocytes in cancer patients are attended with the change of hydration of membrane components. Dielectric properties of the blood were studied in detail in radio-frequency diapason [11-14]. There are no many works that deal with dielectric measurements in UHF diapason [15-17].

\section{The ground of research}

An influence of temperature on the state of components of cytoskeleton and cellular membrane is direct it is not mediated with the changes of such macroscopic parameters of the cell as volume and form [18]. For this factor can be separated the specific component of influence that is the change of phase-structural state of membrane [19-21]. The structural reconstructions of erythrocyte membranes induced by the temperature cause the changes of solvent (water) structure [22, 23]. The possibility of the use of UHF-dielectrometry method for the study of relaxation frequency of substances particularly the dielectric relaxation frequency of the water molecules in erythrocyte membranes is determined by the fact that the molecules of the bound water and dissolved substance in centimeter wavelengths diaposon 
are less movable than the molecules of the free water $[24,25]$. In this case almost all water molecules are in the bound state and enter into composition of hydrated layers of salts and boimacromolecules of cellular membranes where it function as a shock absorber at abrupt external changes ensuring the survival of cells [26]. Dielectric permeability of the erythrocyte membranes is an important parameter that reflects the structural state of the water in cells and defines the value of intermolecular interactions in systems containing water as a solvent [25, $27,28]$. As far as the content and properties of erythrocyte membranes change in the specific way at different diseases the great number of clinical diagnostics methods are based on analysis of the physical parameters and additional information is needed for calculation of these parameters and it can be received only by the different kind of experiments. An elaboration of methods for an early diagnostics of pathology based on analysis of dielectric parameters of the blood erythrocytes allows receive an additional information about the state of cells and erythrocyte membranes in conditions of mutagenic influence of malignant disease $[9,10]$.

\section{Aim of research}

The aim of research was the study of dielectric relaxation frequency of the water molecules in suspensions and erythrocytes ghosts of donors and cancer patients in temperature interval $1-46^{\circ} \mathrm{C}$.

\section{Materials and methods}

For research there were used suspensions and erythrocyte ghosts of the blood of 28 healthy donors and 62 patients with breast cancer, lung cancer (1-111 stages by TNM classification) of an average age $47 \pm 4$ years. The method of preparation of patterns was described in details earlier [29]. Examination of dielectric characteristics of suspensions of erythrocytes and its ghosts in temperature area from 1 to $46{ }^{\circ} \mathrm{C}$ was carried out on UHF-dielecrometer of resonator type on frequency 9,2 Ghz $[30,31]$. Transition from values $\varepsilon^{\prime}$ and $\varepsilon^{\prime \prime}$ directly measured in experiment to the value $f_{d}$-dielectric relaxation frequency of the water in solution was realized with a help of Debye equation [30, 31]. The activation energy of dipole relaxation $\Delta \mathrm{F}$ of the water molecules in studied systems was get from the ratio [32]:

$$
\tau=\frac{\mathrm{hN}}{\mathrm{RT}} \exp \left(\frac{\Delta \mathrm{F}}{\mathrm{RT}}\right),
$$

where $\tau$ - time of dielectric relaxation, $\mathrm{h}$ - Planck constant, R - gas constant, N - Avogadro number. The received results were processed using methods of variation statistics.

\section{Results of research}

The temperature dependence of an actual $\varepsilon^{\prime}$ and imaginary $\varepsilon^{\prime \prime}$ parts of complex dielectric permeability for suspensions of erythrocytes and suspension of erythrocyte ghosts of donors and cancer patients are presented in Tables 1-4.
Table 1

Temperature dependence of an actual $\varepsilon^{\prime}$ and imaginary $\varepsilon^{\prime \prime}$ parts of complex dielectric permeability for suspension of erythrocytes of donors and of patients with breast cancer

\begin{tabular}{|c|c|c|c|c|}
\hline \multicolumn{5}{|c|}{ Dynamics of indicators } \\
\hline & \multicolumn{2}{|c|}{ Donors $(\mathrm{n}=28)$} & Cancer patients $(\mathrm{n}=31)$ \\
\hline $\mathrm{T},{ }^{\circ} \mathrm{C}$ & $\varepsilon^{\prime}$ & $\varepsilon^{\prime \prime}$ & $\varepsilon^{\prime}$ & $\varepsilon^{\prime \prime}$ \\
\hline 1 & $36,1 \pm 1,1$ & $35,1 \pm 0,7$ & $41,2 \pm 1,2^{*}$ & $34,0 \pm 0,8$ \\
\hline 5 & $41,6 \pm 1,2$ & $33,6 \pm 0,8$ & $44 \pm 0,8$ & $32,9 \pm 0,9$ \\
\hline 10 & $43,2 \pm 1,1$ & $32,6 \pm 0,8$ & $46,5 \pm 1,1^{*}$ & $30,0 \pm 1,0^{*}$ \\
\hline 15 & $47,8 \pm 1,2$ & $30,0 \pm 1,1$ & $50,2 \pm 1,1$ & $29,9 \pm 1,0$ \\
\hline 20 & $51,1 \pm 1,0$ & $27,3 \pm 0,7$ & $53,3 \pm 0,9$ & $26,5 \pm 1,2$ \\
\hline 25 & $53,3 \pm 1,3$ & $25,3 \pm 1,1$ & $56,7 \pm 1,1^{*}$ & $24,5 \pm 1,1$ \\
\hline 30 & $54,3 \pm 1,3$ & $23,5 \pm 0,9$ & $57,6 \pm 1,0^{*}$ & $22,4 \pm 1,0$ \\
\hline 35 & $55,4 \pm 1,1$ & $21,4 \pm 1,0$ & $58,4 \pm 0,9^{*}$ & $19,2 \pm 1,1$ \\
\hline 40 & $56,5 \pm 1,2$ & $19,8 \pm 0,8$ & $58,6 \pm 0,8^{*}$ & $18,6 \pm 0,7$ \\
\hline 46 & $57,0 \pm 1,0$ & $18,4 \pm 0,4$ & $59,9 \pm 1,2^{*}$ & $16,2 \pm 1,0 *$ \\
\hline
\end{tabular}

Table 2

Temperature dependence of an actual $\varepsilon^{\prime}$ and imaginary $\varepsilon^{\prime \prime}$ parts of complex dielectric permeability for suspension of erythrocytes of donors and patients with lung cancer

\begin{tabular}{|c|c|c|c|c|}
\hline \multicolumn{5}{|c|}{ Dynamics od indicators } \\
\hline & \multicolumn{2}{|c|}{ Donors $(\mathrm{n}=28)$} & \multicolumn{2}{c|}{ Cancer patients $(\mathrm{n}=31)$} \\
\hline $\mathrm{T},{ }^{\circ} \mathrm{C}$ & $\varepsilon^{\prime}$ & $\varepsilon^{\prime \prime}$ & $\varepsilon^{\prime}$ & $\varepsilon^{\prime \prime}$ \\
\hline 1 & $36,1 \pm 1,3$ & $35,1 \pm 1,3$ & $41,2 \pm 1,1^{*}$ & $38,8 \pm 1,1^{*}$ \\
\hline 5 & $41,6 \pm 1,2$ & $33,6 \pm 0,7$ & $43,3 \pm 1,3$ & $37,8 \pm 0,8^{*}$ \\
\hline 10 & $43,2 \pm 1,1$ & $32,6 \pm 0,8$ & $48,0 \pm 1,3^{*}$ & $35,6 \pm 1,0^{*}$ \\
\hline 15 & $47,8 \pm 1,2$ & $30,0 \pm 1,1$ & $50,4 \pm 1,2$ & $29,8 \pm 1,3$ \\
\hline 20 & $51,1 \pm 1,0$ & $27,3 \pm 0,7$ & $55,9 \pm 1,4^{*}$ & $27,5 \pm 1,2$ \\
\hline 25 & $53,3 \pm 1,3$ & $25,3 \pm 1,1$ & $57,5 \pm 1,3^{*}$ & $27,0 \pm 1,3$ \\
\hline 30 & $54,3 \pm 1,3$ & $23,5 \pm 0,9$ & $58,4 \pm 1,4^{*}$ & $25,0 \pm 0,8^{*}$ \\
\hline 35 & $55,4 \pm 1,1$ & $21,4 \pm 1,0$ & $59,3 \pm 1,2^{*}$ & $22,6 \pm 1,0$ \\
\hline 40 & $56,5 \pm 1,2$ & $19,8 \pm 0,8$ & $59,6 \pm 0,8^{*}$ & $19,6 \pm 1,3$ \\
\hline 46 & $57,0 \pm 1,0$ & $18,4 \pm 0,4$ & $60,7 \pm 1,1^{*}$ & $18,8 \pm 1,0$ \\
\hline
\end{tabular}

Note: * - reliability in comparison with control (donors), $p \leq 0,05$

Table 3

Temperature dependence of an actual $\varepsilon^{\prime}$ and imaginary $\varepsilon^{\prime \prime}$ parts of complex dielectric permeability for suspension of erythrocyte ghosts of donors and patients with breast cancer

\begin{tabular}{|c|c|c|c|c|}
\hline \multicolumn{5}{|c|}{ Dynamics of indicators } \\
\hline & \multicolumn{2}{|c|}{ Donors $(\mathrm{n}=28)$} & \multicolumn{2}{c|}{ Cancer patients $(\mathrm{n}=31)$} \\
\hline $\mathrm{T},{ }^{\circ} \mathrm{C}$ & $\varepsilon^{\prime}$ & $\varepsilon^{\prime \prime}$ & $\varepsilon^{\prime}$ & $\varepsilon^{\prime \prime}$ \\
\hline 1 & $44,8 \pm 1,2$ & $40,4 \pm 0,9$ & $40,9 \pm 1,1^{*}$ & $38,7 \pm 0,9$ \\
\hline 5 & $47,6 \pm 1,1$ & $39,8 \pm 0,9$ & $44,3 \pm 0,8^{*}$ & $38,4 \pm 0,7$ \\
\hline 10 & $52,2 \pm 1,1$ & $37,8 \pm 0,8$ & $48,0 \pm 1,2^{*}$ & $36,7 \pm 1,0$ \\
\hline 15 & $57,2 \pm 1,2$ & $36,5 \pm 1,2$ & $54,0 \pm 1,3^{*}$ & $35,7 \pm 1,2$ \\
\hline 20 & $60,6 \pm 1,0$ & $31,2 \pm 0,7$ & $58,6 \pm 0,9$ & $34,3 \pm 1,1^{*}$ \\
\hline 25 & $63,0 \pm 1,3$ & $28,0 \pm 1,0$ & $63,0 \pm 1,1$ & $31,5 \pm 1,1^{*}$ \\
\hline 30 & $65,6 \pm 1,2$ & $26,3 \pm 0,9$ & $66,0 \pm 1,2$ & $28,9 \pm 1,0^{*}$ \\
\hline 35 & $66,3 \pm 1,1$ & $24,1 \pm 1,0$ & $67,3 \pm 1,1$ & $25,3 \pm 0,9$ \\
\hline 40 & $66,4 \pm 1,1$ & $21,1 \pm 0,9$ & $69,3 \pm 0,9^{*}$ & $22,3 \pm 0,8$ \\
\hline 46 & $67,0 \pm 1,0$ & $19,5 \pm 0,9$ & $69,6 \pm 1,2$ & $19,8 \pm 1,0$ \\
\hline
\end{tabular}

Note: * - reliability of differences in comparison with control (donors), $p \leq 0,05$ 
Table 4

Temperature dependence of an actual $\varepsilon^{\prime}$ and imaginary $\varepsilon^{\prime \prime}$ parts of dielectric permeability for suspension of erythrocyte ghosts of donors and patients with lung cancer

\begin{tabular}{|c|c|c|c|c|}
\hline \multicolumn{5}{|c|}{ Dynamics of indicators } \\
\hline & \multicolumn{2}{|c|}{ Donors $(\mathrm{n}=28)$} & \multicolumn{2}{c|}{ Cancer patients $(\mathrm{n}=31)$} \\
\hline $\mathrm{T},{ }^{\circ} \mathrm{C}$ & $\varepsilon^{\prime}$ & $\varepsilon^{\prime \prime}$ & $\varepsilon^{\prime}$ & $\varepsilon^{\prime \prime}$ \\
\hline 1 & $44,8 \pm 1,2$ & $40,4 \pm 0,9$ & $41,0 \pm 1,0^{*}$ & $37,5 \pm 0,9^{*}$ \\
\hline 5 & $47,6 \pm 1,1$ & $39,8 \pm 0,9$ & $44,3 \pm 1,1^{*}$ & $36,4 \pm 0,9^{*}$ \\
\hline 10 & $52,2 \pm 1,1$ & $37,8 \pm 0,8$ & $54,0 \pm 1,3$ & $34,9 \pm 1,0^{*}$ \\
\hline 15 & $57,2 \pm 1,2$ & $36,5 \pm 1,2$ & $59,6 \pm 1,2$ & $33,0 \pm 1,1^{*}$ \\
\hline 20 & $60,6 \pm 1,0$ & $31,2 \pm 0,7$ & $61,8 \pm 1,0$ & $31,0 \pm 1,0$ \\
\hline 25 & $63,0 \pm 1,3$ & $28,0 \pm 1,0$ & $64,2 \pm 1,2$ & $29,0 \pm 1,0$ \\
\hline 30 & $65,6 \pm 1,2$ & $26,3 \pm 0,9$ & $66,5 \pm 1,1$ & $27,0 \pm 0,9$ \\
\hline 35 & $66,3 \pm 1,1$ & $24,1 \pm 1,0$ & $68,7 \pm 1,1$ & $24,4 \pm 1,0$ \\
\hline 40 & $66,4 \pm 1,1$ & $21,1 \pm 0,9$ & $69,7 \pm 0,9^{*}$ & $21,7 \pm 0,8$ \\
\hline 46 & $67,0 \pm 1,0$ & $19,5 \pm 0,9$ & $70,4 \pm 1,3^{*}$ & $19,5 \pm 1,1$ \\
\hline
\end{tabular}
Note: * - reliability of differences in comparison with control (donors), $p \leq 0,05$

Using the values of indicators of an actual $\left(\varepsilon^{\prime}\right)$ and imaginary $\left(\varepsilon^{\prime \prime}\right)$ parts of complex dielectric permeability of suspension of erythrocytes and suspension of erythrocyte ghosts of donors and cancer patients, the dielectric relaxation frequency $\left(f_{d}\right)$ of the water molecules in studied systems was calculated by the formula: $f_{d}=f\left(\varepsilon^{\prime}-\varepsilon_{\infty}\right) / \varepsilon^{\prime \prime}$, where $\mathrm{f}_{\mathrm{d}}$ - and $\mathrm{f}$ - dielectric relaxation frequency and microwave field frequency respectively, $\varepsilon_{\infty}=5,5$ (dielectric permeability of the studied objects in IR- diapason) [31]. Dielectric relaxation frequency $\left(f_{d}\right)$ of the water molecules is a parameter that characterizes the mobility of molecules in UHF field and so the degree of its interaction with surrounding solution. Temperature dependencies of the dielectric relaxation frequency $f_{d}$ of the water molecules in suspensions of erythrocytes in sodium chloride and also dependency of dielectric relaxation frequency $f_{d}$ of the water molecules in suspensions of erythrocytes ghosts in sodium chloride of donors and cancer patients received according to the data of Tables 1-4 are presented on Fig. 1-4.

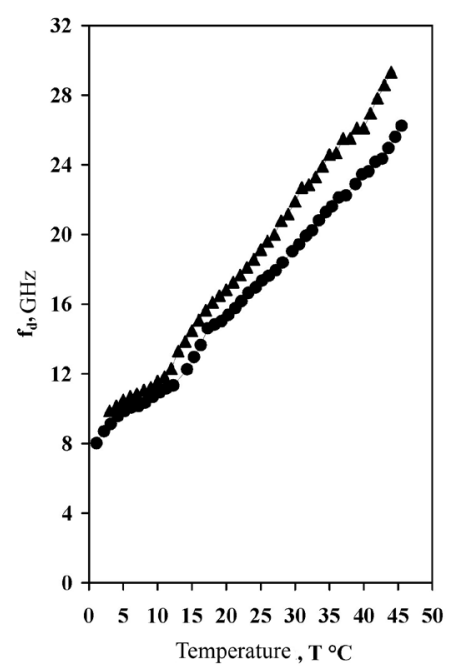

Fig. 1. Temperature dependence of dielectric relaxation frequency $f_{d}$ of the water molecules in suspension of erythrocytes: $\bullet-$ donors, $\boldsymbol{\Delta}$ - patients with breast cancer

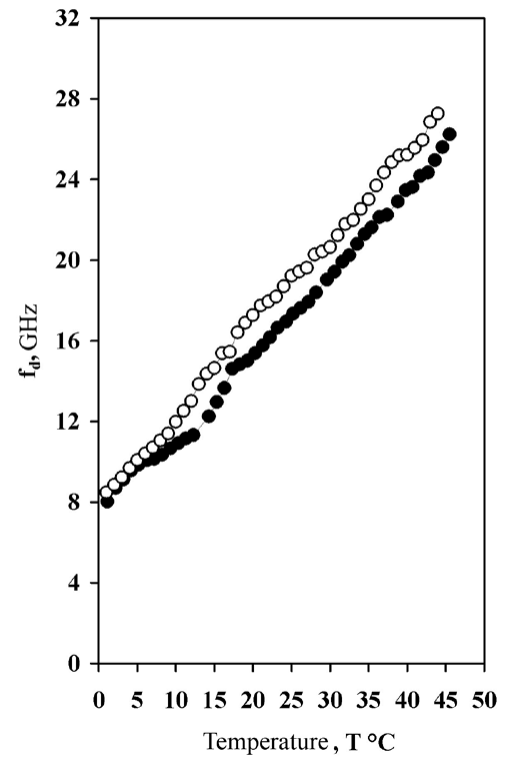

Fig. 2. Temperature dependence of dielectric relaxation frequency $f_{d}$ of the water molecules in suspension of erythrocytes: - - donors, $\bigcirc-$ patients with lung cancer

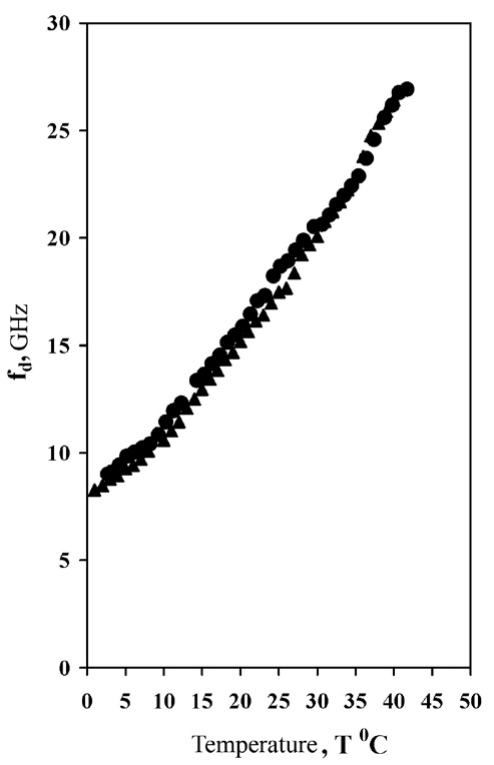

Fig. 3. Temperature dependence of dielectric relaxation frequency $f_{d}$ of the water molecules in suspension of erythrocyte ghosts: $\bullet-$ donors $\boldsymbol{\Delta}$ - patients with breast cancer

For suspension of donor erythrocytes in temperature interval $6-12{ }^{\circ} \mathrm{C}, 17-40{ }^{\circ} \mathrm{C}$ and $43-46{ }^{\circ} \mathrm{C}$ there are observed breaks attended with an increase of energy of activation for $18,4 \mathrm{~kJ} / \mathrm{mole}$ at $12^{\circ} \mathrm{C}$, decrease for $4,6 \mathrm{~kJ} / \mathrm{mole}$ at $37^{\circ} \mathrm{C}$ and growth of energy of activation in temperature interval $43-46{ }^{\circ} \mathrm{C}$ for $17,31 \mathrm{~kJ} /$ mole. For suspension of erythrocytes of cancer patients the changes of energy of activation are observed in temperature diapason $9-18^{\circ} \mathrm{C}$, $43-46{ }^{\circ} \mathrm{C}$ (breast cancer) and $23-37^{\circ} \mathrm{C}$ (lung cancer) that is attended with the change of dielectric relaxation frequency of $\mathrm{H}_{2} \mathrm{O}$ molecules. For patients with breast cancer there is observed an increase of energy of activation in diapason 
9-18 ${ }^{\circ} \mathrm{C}$ for $9,8 \mathrm{~kJ} /$ mole and for $14,7 \mathrm{~kJ} /$ mole in interval $43-46{ }^{\circ} \mathrm{C}$. For patients with lung cancer the respective indicators decrease for $8,3 \mathrm{~kJ} / \mathrm{mole}$ at temperature $23-37{ }^{\circ} \mathrm{C}$.

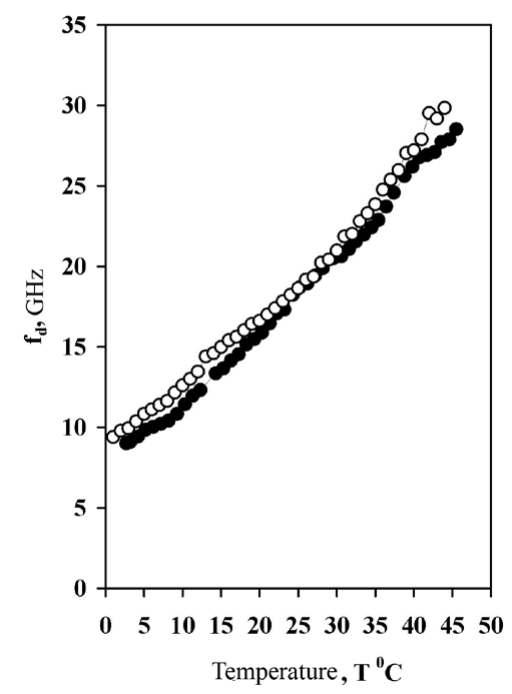

Fig. 4. Temperature dependence of dielectric relaxation frequency $f_{d}$ of the water molecules in suspension of erythrocyte ghosts:

- - donors, ○- patients with lung cancer

\section{Discussion of results}

Cancer disease realizing a significant mutagenic influence on organism also has an influence on functions of erythrocyte membranes and it is an additional factor that indirectly takes part in damage of blood cell membranes structure of cancer patients. The diagram of temperature dependence of dielectric relaxation frequency of the water molecules in suspensions of erythrocytes (Fig. 1,2) demonstrates an increase of relaxation frequency $f_{d}$ of the water molecules in suspensions of erythrocytes of patients with breast and lung cancer compared with donors. This effect is observed on the whole studied temperature interval that is logically connected with changes of physical and chemical properties of erythrocyte membranes and with dysfunctions of the blood formation revealed at the presence of tumor in organism $[10,33,34]$. The specificity of changes can be caused by LPO activation that causes the damage of lipid spectrum of erythrocyte membrane especially the decrease of content of common lipids and phosphatidylcholine (PC) fraction at an increase of the level of lysophosphatidylcholine and phosphatidyl inositol fractions that leads to dehydration of erythrocytes. An increase of the content of saturated fatty acids and decrease of the level of unsaturated ones in PC and phosphatidylethanolamineane fractions stimulate an increase of microviscosity of the deep and modification of the external layers of erythrocyte membranes [34]. An appearance of additional hydrogen bonds can explain the decrease of $f_{d}$ at $6-12{ }^{\circ} \mathrm{C}$ in suspension of donor erythrocytes compared with dielectric relaxation frequency $f_{d}$ of the water molecules in suspension of erythrocytes of patients. This process demonstrates the hindered rotation of the water molecules and decrease of amount of the bound water that is probably connected with depression of the blood formation and an increase of concentration of the tumor necrosis factor in blood [35-38]. An increase of the number of abnormal erythrocytes in bloodstream (echinocytes, stomacytes, sferocytes and the old erythrocytes) that ensures the decrease of elasticity and mobility of the blood cells stimulates an erythrocytes aggregation. At erythrocytes aggregation in conditions of cancer disease takes place an overlap of hydration layers of approximate cells that by-turn influences on decrease of erythrocytes hydration. As far as energy of activation of hydrogen bond is evaluated in $12,5 \mathrm{~kJ} / \mathrm{mole}$ [39], every water molecule in the studied systems forms $1,2-1,4 \mathrm{H}$-bonds with neighboring molecules. The change of slope of temperature dependence in temperature interval $9-18{ }^{\circ} \mathrm{C}$ can indicate a structural reconstruction of erythrocyte membrane of cancer patients and an appearance of cells with low-density internal structure and cavities, crumpled external membrane. Loosening of the surface of membrane leads to the rupture of intramolecular hydrogen bonds that is why the proton-donor and proton-acceptor centers become available for interaction with surrounding water molecules [40]. The presented results give the reason to surmise that the change of indicators of dielectric parameters of suspensions of erythrocytes and its ghosts is connected with damage of the specific channels of ions leakage [41, 42], and with general increase of imperfection of membranes of cancer patients at deformation under an influence of temperature. This effect intensifies at lowering of the temperature of medium that is probably connected with the local temperature depending transitions of the lipid components of membranes.

\section{Conclusions}

1. There was studied an influence of temperature in broad interval of doses $\left(1 \div 46{ }^{\circ} \mathrm{C}\right)$ on dielectric properties of erythrocytes of donors and cancer patients. The received values of an actual $\varepsilon^{\prime}$ and imaginary $\varepsilon^{\prime \prime}$ parts of complex dielectric permeability demonstrate the reliability of observed changes.

2. There was detected a declination of temperature dependence from the monotonous type with localization at interimidiary temperatures $6-12{ }^{\circ} \mathrm{C}$ (for erythrocyte ghosts and erythrocytes of donors and cancer patients) and $42-44{ }^{\circ} \mathrm{C}$ (for erythrocytes of donors and cancer patients). There was established an initiation of transmembrane defects that lower the cell resistance to an influence of temperature and also overlap of hydration layers of approximate cells that by-turn has an effect on the decrease of erythrocytes hydration.

3. There was established the higher probability of initiation of defects in erythrocyte membranes of cancer patients in temperature interval $43-46{ }^{\circ} \mathrm{C}$ compared with temperature area $9-18{ }^{\circ} \mathrm{C}$ and the lower probability of its locking compared with temperature area $23-37^{\circ} \mathrm{C}$.

\section{References}

1. Rak v Ukrai'ni, 2013-2014. Zahvorjuvanist', smertnist', pokaznyky dijal'nosti onkologichnoi' sluzhby. Bjul. Nac. kancerrejestru Ukrai’ny [Text]. - Kyi’v, 2015. - № 16.

2. Bolis, L. S. Membrany i bolezn' [Tekst] / L. S. Bolis, D. F. Hoffman, A. Lif; L. S. Bolis (Ed.). - Moscow: Medicina, 1980. $-408 \mathrm{p}$. 
3. Morariu, V. V. Water diffusion through erythrocyte membranes in normal and pathological subjects: nuclear magnetic resonance investigations [Text] / V. V. Morariu, Ch. Benga. - Membrane Process. New York: E. A., 1984. - P. 121-139. doi: 10.1007/978-1-4613-8274-4

4. Komarov, F. I. Biohimicheskie issledovanija v klinike [Text] / F. I. Komarov, B. F. Korovkin, V. V. Men'shikov. - Lviv: Medicina, 1981. - 406 p.

5. Schwan, H. P. Electrical properties of cells: Principles, some recent results and some unresolved problems [Text] / H. P. Schwan // The biophysical approach to excitable systems. Plenum Press. - New York, 1981. - P. 3-24. doi: 10.1007/9781-4613-3297-8_1

6. Grshcenko, V. I. Vlijanie temperatury i koncentracii razlichnyh veshhestv na mikrovjazkost' citozolja jeritrocitov [Text] / V. I. Grshcenko, S. H. Mezhidov, V. A. Moiseev, O. A. Nardid // Biofizika. - 1995. - Vol. 40, Issue 1. - P. 106-109.

7. Verbavatz, J. M. Tetrameric assembly of CHIP28 water channels in liposomes and cell membranes: a freeze-fracture study [Text] / J. M. Verbavatz, D. Brown, I. Sabolic // Journal of Cell Biology. - 1993. - Vol. 123, Issue 3. - P. 605-618. doi: $10.1083 /$ jcb.123.3.605

8. Antonchenko, V. Ja. Mikroskopicheskaja teorija vody v porah membran [Tekst] / V. Ja. Antonchenko. - Kiev.: Nauk. dumka, 1983. - $160 \mathrm{p}$.

9. Becker, F. F. Separation of human breast cancer cells from blood by differential dielectric affinity [Text] / F. F. Becker, X. B. Wang, Y. Huang, R. Pethig, J. Vykoukal, P. R. Gascoyne // Proceedings of the National Academy of Sciences. - 1995. - Vol. 92, Issue 3. - P. 860-864. doi: 10.1073/ pnas. 92.3 .860

10. Zhuravljov, A. K. Membrany jeritrocitov pri zlokachestvennom roste [Tekst] / A. K. Zhuravljov, V. V. Murashko // Bjul. Jeksperimental'noj biologii i mediciny. - 1984. Vol. 98, Issue 11. - P. 596-598.

11. Chelidze, T. Dielectric spectroscopy of blood [Text] / T. Chelidze // Journal of Non-Crystalline Solids. 2002. - Vol. 305, Issue 1-3. - P. 285-294. doi: 10.1016/s00223093(02)01101-8

12. Schwan, H. P. Electrical properties of the plasma membrane of erythrocytes at low frequencies [Text] / H. P. Schwan, T. P. Bothwell // Nature. - 1956. - Vol. 178, Issue 4527. P. 265-266. doi: 10.1038/178265b0

13. Asami, K. Dielectric dispersion of erythrocyte ghosts [Text] / K. Asami // Physical Review E. - 2006. - Vol. 73, Issue 5. - P. 052903-052905. doi: 10.1103/physreve.73.052903

14. Kotb, M. A. Dielectric properties of red blood corpuscles of workers chronically exposed to benzene in workplace [Text] / M. A. Kotb, H. S. Ramadan // European Scientific Journal June. - 2014. - Vol. 10, Issue 18. - P. 365-378.

15. Solov'ev, D. V. Dijelektricheskaja pronicaemost' jeritrocitov krolej na chastote 9,2 GGc pri diabete 2 tipa i primenenii saharosnizhajushhih sredstv [Text] / D. V. Solov'ev, O. A. Gorobchenko, T. A. Shatalova et. al. // Biofizichnij visnik. - 2011. - Vol. 27, Issue 2. - P. 40-49.

16. Zhiljakova, T. A. Temperaturozavisimye izmenenija sostojanija vody $\mathrm{v}$ biologicheskih membranah po dannym metodov JaMR i SVCh-dijelektrometrii [Text]: dis. ... kad. biol. nauk / T. A. Zhiljakova. - Har'kov, 1991. - 170 p.
17. Cleary, S. F. Radiofrequency. Microwave Cell Absorption and Action Spectroscopy [Text] / S. F. Cleary, L. M. Liu. Technical Report, 1988. - 15 p.

18. Mamotjuk, E. M. Issledovanija termoustojchivosti frakcij jeritrocitov $\mathrm{v}$ norme i pri onkologicheskoj patologii [Text]: tez. III Z'izda z radiacijnih doslidzhen' (radiobiologija i radioekologija) / E. M. Mamotjuk, L. V. Batjuk, I. A. Leonova, V. I. Urazova. - Kiiv, 2003. - 235 p.

19. Batyuk, L. V. Influence of temperature of the aggregation of erythrocytes in patients with malignant neoplasms [Text]: tezi dopovidej Ukrains'kogo Tovaristva klitinnoi biologii / L. V. Batyuk, S. V. Gatash, V. V. Tovstiak. - L'viv, 2004. - 66 p.

20. Batjuk, L. V. Analiz zmin pokaznykiv kyslotnogo gemolizu i termorezystentnosti erytrocytiv pry promenevoi' terapii' zlojakisnyh zahvorjuvan' [Tekst] / L. V. Batjuk // Ukrai'ns'kyj Radiologichnyj zhurnal. - 2004. - Vol. 12, Issue 4. P. 135-141.

21. Borisova, A. G. Analiz izmenenij termorezistentnosti jeritrocitov pri rake legkogo [Text] / A. G. Borisova, E. K Olejnik // Klinicheskaja laboratornaja diagnostika. - 2001. - Vol. 5. P. 14-16.

22. Gasan, A. I. Termicheskie perestrojki po gidratacija syvorotochnogo al'bumina [Text] / A. I. Gasan, V. A. Kashpur, V. Ja. Maleev // Biofizika. - 1994. - Vol. 39, Issue 2. P. 588-593.

23. Haggis, G. H. The dielectric properties of water in solutions [Text] / G. H. Haggis, J. B. Hasted, T. J. Buchan // Journal of Chemical Physics. - 1952. - Vol. 20, Issue 9. P. $1453-1456$.

24. Frjolih, G. Teorija dijelektrikov. Dijelektricheskaja pronicaemost' i dijelektricheskie poteri [Tekst] / G. Frjolih. Moscow: Izd-vo IL, 1960. - $251 \mathrm{p}$.

25. Cook, H. F. Dielectric behaviour of human blood at microwave frequencies [Text] / H. F. Cook // Nature. - 1951. Vol. 168, Issue 4267. - P. 247-248. doi: 10.1038/168247a0

26. Tiffert, T. The hydration state of human red blood cells and their susceptibility to invasion by Plasmodium falciparum [Text] / T. Tiffert, V. L. Lew, H. Ginsburg, M. Krugliak, L. Croisille, N. Mohandas // Blood. - 2005. - Vol. 105, Issue 12. P. 4853-4860. doi: 10.1182/blood-2004-12-4948

27. Dix, J. A. Role of membranes protein and lipids in water diffusion across red cell membranes $[$ Text] / J. A. Dix, A. K. Solomon // Biochim. Biophys. Acta. - 1984. - Vol. 773, Issue 2. - P. 219-230. doi: 10.1016/0005-2736(84)90085-3

28. Schwan, H. P. Dielectric properties of membrane of lysed erythrocytes [Text] / H. P. Schwan, E. L. Carstensen // Science. - 1957. - Vol. 125, Issue 3255. - P. 985-986. doi: 10.1126/ science.125.3255.985

29. Batjuk, L. V. Dielectric properties of human erythrocytes in normal and carcinogenic state [Text] / L. V. Batjuk, S. V. Gatash, O. A. Gorobchenko, O. T. Nikolov // Vestnik Har'kovskogo universiteta. Biofizicheskij vestnik. - 2002. Vol. 1 (10), Issue 560. - P. 54-57.

30. Nikolov, O. T. Izmerenie kompleksnoj dijelektricheskoj pronicaemosti zhidkih dijelektrikov s bol'shimi poterjami [Text] / O. T. Nikolov, T. A. Zhiljakova // Zhurnal fizicheskoj himii. - 1991. - Vol. 65, Issue 5. - P. 1312-1316.

31. Hackl, E. V. Using UHF-dielectrometry to study protein structural transitions [Text] / E. V. Hackl, S. V. Gatash, 
O. T. Nikolov // Journal of Biochemical and Biophysical Methods. - 2005. - Vol. 63, Issue 2. - P. 137-148. doi: 10.1016/j.jbbm. 2005.04.002

32. Glesston, S. Teorija absoljutnyh skorostej reakcij [Text] / S. Glesston, K. Lejder, G. Jejring. - Moscow: IIL, 1948. $-584 \mathrm{p}$.

33. Baeva, E. V. Insulin deponirujushhaja funkcija jeritrocitov pri rake molochnoj zhelezy [Text] / E. V. Baeva // Jeksperimental'naja onkologija. - 1979. - Vol. 1, Issue 1. - P. 69-70.

34. Hyshiktuev, B. S. Zhirno-kislotnyj sostav lipidov plazmy krovi i jeritrocitov u bol'nyh rakom legkogo [Text] / B. S. Hyshiktuev, N. A. Hyshiktueva, V. N. Ivanov et. al. // Vopr. med. himii. - 1994. - Vol. 40, Issue 5. - P. 48-50.

35. Berezhnaja, N. M. Rol' kletok sistemy immuniteta $\mathrm{V}$ mikrookruzhenii opuholi. Kletki i citokiny - uchastniki vospalenija [Text] / N. M. Berezhnaja // Onkologija. - 2009. - Vol. 11, Issue 1. - P. 6-17.

36. Berezhnaja, N. M. Immunologija zlokachestvennogo rosta [Text] / N. M. Berezhnaja, V. F. Chehun. - Kiev: Nauk, dumka, 2005. $-792 \mathrm{p}$.

37. Bljum, N. E. Osobennosti citokinovogo balansa pri hroni $\neg$ cheskoj obstruktivnoj bolezni legkih [Text] / N. E. Bljum, A. R. Antonov, R. R. Asadullina et. al. // Ross. med. zhurn. 2006. - Vol. 14, Issue 22. - P. 34-39.

38. Tan, T. T. Humoral immunity, inflammation and cancer [Text] / T. T. Tan, L. M. Coussens // Current Opinion in Immunology. - 2007. - Vol. 19, Issue 2. - P. 209-216. doi: 10.1016/j.coi.2007.01.001

39. Gordon, D. Organicheskaja himija rastvorov jelektrolitov [Text] / D. Gordon. - Moscow: Mir, 1979. - 712 p.

40. Potapov, A. A. Dijelektricheskie svojstva vody i protonno-aktivacionnyj mehanizm poljarizacii [Text] / A. A. Potapov // Zhurnal obshhej himii. - 1993. - Vol. 63, Issue 7. P. 1461-1471.

41. Sorokina, Z. A. Sostojanie kalija, natrija i vody v citoplazme kletok [Text] / Z. A. Sorokina. - Kiev: Nauk. dumka, 1978. $-212 \mathrm{p}$.

42. Bjerrum, P. J. The Red Cell Membrane: A Model for Solute Transport [Text] / Bjerrum, P. J.; B. U. Raess, G. Tunnicliff (Eds.). - The human Press Inc., 1989. - 465 p.

\section{References}

1. Cancer in Ukraine, 2013-2014. Bulletin of national cancer registry of Ukraine (english) (2015). Ukrainian cancer registry statistics, 16 .

2. Bolis, L. S., Hoffman, D. F., Lif, A. (1980). Membranu i bolezn' [Membranu i bolezn']. Moscow: Medicine, 408.

3. Morariu, V. V., Benga, G. (1984). Water diffusion through erythrocyte membranes in normal and pathological subjects: nuclear magnetic resonance investigations. Membrane processes, 121-139. doi: 10.1007/978-1-4613-8274-4

4. Komarov, F. I., Korovkin, B. F., Menshikov, V. V. (1981). Biohimicheskie issledovaniya v klinike [Biohimicheskie issledovaniya v klinike]. Lviv: Medicine, 406.

5. Schwan, H. P. (1981). Electrical Properties of Cells: Principles, Some Recent Results, and Some Unresolved Problems. The Biophysical Approach to Excitable Systems, 3-24. doi: 10.1007/978-1-4613-3297-8_1

6. Grshcenko, V. I., Magidov, S. H., Moiseev, V. A., Nadrid, O. A. (1995). Vlijanie temperatyru i consentrasij razlichnux veschestv na mikrovjazkost' citozolja jeritrocitov. Biofizika, 40 (1), 106-109.

7. Verbavatz, J. M., Brown, D., Sabolic, I. (1993). Tetrameric assembly of CHIP28 water channels in liposomes and cell membranes: a freeze-fracture study. The Journal of Cell Biology, 123 (3), 605-618. doi: 10.1083/jcb.123.3.605

8. Antonchenko, V. Ya. (1983). Mikroskopicheskaya teoriya vody [Mikroskopicheskaya teoriya vody]. Naukova dumka, 160.

9. Becker, F. F., Wang, X. B., Huang, Y., Pethig, R., Vykoukal, J., Gascoyne, P. R. (1995). Separation of human breast cancer cells from blood by differential dielectric affinity. Proceedings of the National Academy of Sciences, 92 (3), 860-864. doi: 10.1073/pnas.92.3.860

10. Guravlev, A. K., Myrahko, V. V. (1984). Membranu jeritrocitov pri zlokachestvennom roste. Bulletin of Experimental Biology and Medicine, 98 (11), 596-598.

11. Chelidze, T. (2002). Dielectric spectroscopy of blood. Journal of Non-Crystalline Solids, 305 (1-3), 285-294. doi: 10.1016/s0022-3093(02)01101-8

12. Bothwell, T. P., Schwan, H. P. (1956). Electrical Properties of the Plasma Membrane of Erythrocytes at Low Frequencies. Nature, 178 (4527), 265-266. doi: 10.1038/178265b0

13. Asami, K. (2006). Dielectric dispersion of erythrocyte ghosts. Physical Review E, 73 (5), 052903-052905. doi: 10.1103/physreve.73.052903

14. Kotb, M. A., Ramadan, H. S. (2014). Dielectric properties of red blood corpuscles of workers chronically exposed to benzene in workplace. European Scientific Journal June, 10 (18), 365-378.

15. Solov'ev, D. V., Gorobchenko, T. A., Shatalova, T. A. et al. (2011). Dijelektricheskaja pronicaemost' jeritrocitov krolej na chastote $9,2 \mathrm{GGc}$ pri diabete 2 tipa i primenenii saharosnizhajushhih sredstv. Biofizichnij visnik, 27 (2), 40-49.

16. Zhiljakova, T. A. (1991). Temperaturozavisimye izmenenija sostojanija vody $\mathrm{v}$ biologicheskih membranah po dannym metodov JaMR i SVCh-dijelektrometrii. Kharkiv, 170.

17. Cleary, S. F., Liu, L. M. (1988). Radiofrequency/ Microwave Cell Absorption and Action Spectroscopy. Technical Report, 15.

18. Mamotyuk, E. M., Batyuk, L. V., Leonova, I. A., Yrazova, V. I. (2003). Issledovaniya termoystoichivosti fraksij jeritrocitov v norme i pri patologii. III Congress on radiation research (radiobiology and radioecology). Kiev, 235.

19. Batyuk, L. V., Gatash, S. V., Tovstiak, V. V. (2004). Influence of temperature of the aggregation of erythrocytes in patients with malignant neoplasms. Abstracts of Ukrainian Society of Cell Biology. Lviv, 66.

20. Batyuk, L. V. (2004). The analysis of acid hemolysis parameters and erythrocyte thermal resistance at radiation therapy of malignant tumors. Ukrainian Journal of Radiology, 12 (4), 135-141.

21. Borisova, A. G., Olejnik, E. K. (2001). Analiz izmenenij termorezistentnosti jeritrocitov pri rake legkogo. Klinicheskaja laboratornaja diagnostika, 5, 14-16.

22. Gasan, A. I., Kashpyr, V. A., Maleev, V. Ja. (1994). Termicheskie perestroiki sivorotochnogo albumina. Biofizika, 39 (2), 588-593.

23. Haggis, G. H., Hasted, J. B., Buchan, T. J. (1952). The dielectric properties of water in solutions. Journal of Chemical Physics, 20 (9), 1453-1456. 
24. Frelih, G. (1960). Teorija dijelektrikov [Teorija dijelektrikov]. Moscow: Izd-vo IL, 251.

25. Cook, H. F. (1951). Dielectric Behaviour of Human Blood at Microwave Frequencies. Nature, 168 (4267), 247-248. doi: $10.1038 / 168247 \mathrm{a} 0$

26. Tiffert, T., Lew, V. L., Ginsburg, H., Krugliak, M., Croisille, L., Mohandas, N. (2005). The hydration state of human red blood cells and their susceptibility to invasion by Plasmodium falciparum. Blood, 105 (12), 4853-4860. doi: 10.1182/ blood-2004-12-4948

27. Dix, J. A., Solomon, A. K. (1984). Role of membrane proteins and lipids in water diffusion across red cell membranes. Biochimica et Biophysica Acta (BBA) - Biomembranes, 773 (2), 219-230. doi: 10.1016/0005-2736(84)90085-3

28. Schwan, H. P., Carstensen, E. L. (1957). Dielectric Properties of the Membrane of Lysed Erythrocytes. Science, 125 (3255), 985-986. doi: 10.1126/science.125.3255.985

29. Batyuk, L. V., Gatash, S. V., Gorobchenko, O. T., Nikolov, O. T. (2002). Dielectric properties of human erythrocytes in normal and carcinogenic state. Biofizichnij visnik, $1(10(560)), 54-57$.

30. Nikolov, O. T., Zhiljakova, T. A. (1991). Izmerenie kompleksnoj dijelektricheskoj pronicaemosti zhidkih dijelektrikov s bol'shimi poterjami. Zh. fiz. Him, 65 (5), 1312-1316.

31. Hackl, E. V., Gatash, S. V., Nikolov, O. T. (2005). Using UHF-dielectrometry to study protein structural transitions. Journal of Biochemical and Biophysical Methods, 63 (2), 137 148. doi: 10.1016/j.jbbm.2005.04.002

32. Glesston, S., Leder, L. B., Eiring, G. (1948). Teorija absoljutnux skorostej reaksij. Moscow: IIL, 584.
33. Baeva, E. V. (1979). Insulin deponirujashaja funkcija pri rake molochnoi gelezu, 1 (1), 69-70.

34. Hyshiktuev, B. S., Hyshiktueva, N. A., Ivanov, V. N. et al. (1994). The fatty acid composition of lipids of blood plasma and red blood cells in patients with lung cancer. Probl. Med. Chemistry, 40 (5), 48-50.

35. Berezhnaya, N. M. (2009). Role of immune system cells in tumor microenvironment. Cells and cytokines - the components of inflammation. Oncology, 11 (1), 6-17.

36. Berezhnaya, N. M., Chekhun, V. F. (2005). Immunology of tumor growth [Immunology of tumor growth]. Naukova dumka, 792.

37. Blyum, N. E., Antonov, A. P., Asadullina, R. R. et. al. (2006). Osobennosti citikinovogo balanca pri hronocheskoj obstryktivnoj bolezni legkix. Roc.med. zurnal, 14 (22), 34-39.

38. Tan, T.-T., Coussens, L. M. (2007). Humoral immunity, inflammation and cancer. Current Opinion in Immunology, 19 (2), 209-216. doi: 10.1016/j.coi.2007.01.001

39. Gordon, E. (1979). The Organic Chemistry of Electrolyte Solutions. Moscow: Mir, 712.

40. Potapov, A. A. (1993). Dielectric properties of water and proton activation mechanism of polarization. Zurnal obsej himii, 63 (7), 1461-1471.

41. Sorokina, Z. A. (1978). Sostojanie kalija, natrija i vodu v citoplazme kletok [Sostojanie kalija, natrija i vodu v citoplazme kletok]. Naukova dumka, 212.

42. Bjerrum, P. J., Tunnicliff, G. (1989). The Red Cell Membrane: A Model for Solute Transport. The human Press Inc., 465 .

Рекомендовано до публікайї д-р біол. наук Зайцева О. В. Дата надходження рукопису 15.06.2015

Batyuk Liliya, Candidate of Biological Sciences, Department of Medical and Biological Physics and Medical Information Science, Kharkiv National Medical University, Lenina ave., 4, Kharkiv, Ukraine, 61022 E-mail: liliya-batyuk@mail.ru

УДК 616. 993. 1 - 036. 1 - 07 - 085.283

DOI: $10.15587 / 2313-8416.2015 .47258$

\title{
ОПРЕДЕЛЕНИЕ КРИТЕРИЕВ ПРОГНОЗИРОВАНИЯ ЭФФЕКТИВНОСТИ ЛЕЧЕНИЯ ХРОНИЧЕСКОГО ПРИОБРЕТЕННОГО ТОКСОПЛАЗМОЗА
}

\author{
(C) О. В. Боброва
}

Статья посвящена решению проблемы определения критериев прогнозирования эффективности лечения больных хроническим приобретенным токсоплазмозом в стадии обострения до и после комплексной терапии, обоснованию подходов к использоанию наиболее эффективного режима терапии, позволяющего индивидуализировать лечение, определению основных показателей, позволяющих с высокой степенью вероятности рекомендовать различные схемы терапии, а также прогнозированию терапевтического эффекта каждого из видов лечения, в зависимости от исходной патогенетической детерминанать

Ключевые слова: хронический приобретенный токсоплазмоз (ХПТ), прогностические коэффициенть (ПК), информативность (I) признаков, антипротозойная терапия, противотоксоплазмозный иммуноглобулин

The great number of treatment schemes of toxoplasmosis predetermines the question for clinician how to choose the most effective therapy regimen.

Aim. Detection of the criteria of prognostication of efficiency of the treatment patients with the chronic acquired toxoplasmosis (CAT) in an acute phase before and after the complex therapy. 